\title{
Correlation between Outbound Tourism and Foreign Direct Investment from China: Based on Lagging Regression Model
}

\author{
Ying-Ying YANG ${ }^{\mathrm{a}}$ and Ying $\mathrm{CHEN}^{\mathrm{b},{ }^{*}}$ \\ School of geography and tourism, Shaanxi Normal University, Xi'an 710119, China \\ ayyyheart@126.com, ${ }^{b}$ chenying@snnu.edu.cn
}

Keywords: outbound tourism, OFDI, lagging regression model, China

\begin{abstract}
With the expansion of China's outbound tourism, China's outward foreign direct investment(OFDI) in tourism industry has been paid more attention. This paper selected the data of China's outbound tourism and tourism OFDI from 2004 to 2016, and adopted the lagging regression model to demonstrate the quantitative correlation between them. The results showed that: (1) the OFDI of tourism industry would be positively affected by its previous stage; (2)the change rate of outbound tourism and tourism industry OFDI was negatively correlated.
\end{abstract}

\section{Introduction}

Tourism and commerce are inextricably linked from the ancient times. Since the 21st century, China's outbound tourism has developed rapidly, the phenomena and its influence have attracted the attention and discussion of scholars at home and abroad. China's outbound tourism presents a pattern of high growth and high consumption [1]. In 2016, the number of outbound tourists in China was 122 million, while the outbound travel expenditure reached $\$ 108.9$ billion. China's development policy on outbound tourism has also experienced three changes: from moderate development to normative development and then to orderly development . From the evolution of development policy, it is easy to be found that the importance of outbound tourism is going up.

Since China is becoming one of the biggest tourism market to the world, it also creates opportunities for China outward foreign direct investment in tourism industry. The practice of reform and open up shows that FDI plays an important role in promoting economic development. As early as 2009, under the policy of state council about accelerating the development of tourism, the Chinese government has clearly put forward to support qualified tourism enterprises "going out". The issued policy has provided the guidance and support for the internationalization of China's tourism enterprises. In addition, OFDI is one of the ways to weaken the phenomenon of China's high expenditure on outbound tourism[2]-[3]. Japan, as early as the 1970s, was able to earn back the cost of traveling abroad through outward direct investment. Therefore, it is of theoretical and practical significance to study the correlation between outbound tourism and OFDI in tourism industry.

\section{Literature Review}

Tourism investment is a significant field of tourism research, and Chinese scholars mainly focus on domestic tourism investment. Although China's OFDI in tourism industry plays an important role in international trade, the research on this area is limited. The study involving the combination of tourism and foreign investment basically focuses on two aspects:

The first part is FDI in tourism industry. Li et al. [4] analyzed the time and spatial characteristics of OFDI in tourism industry in recent years, and gave relevant policy suggestions. Bao[5] used the grey correlation method to find that the per capita GDP and the amount of inbound and outbound tourists are the related factors of FDI development in China's tourism industry. Adrian Bull[6] studied the benefits of foreign investment in Australia's tourism industry. William Purcell and Stephen Nicholas[7] investigated the regional selection of Japan's FDI in Australia and how do the home country control and manage enterprises. Kumi Endo[8] studied the flow of international tourism FDI, and revealed the model and scale of outbound investment in tourism. QiuZhang [9] et 
al. demonstrated what determined the cross-border hotel groups' choice on tourism investment location in China.

Another part is the relationship between international and FDI. Gao [10] found a long-term equilibrium relationship between inbound tourism and FDI in China. Wan et al. [11], Tang et al. [12] indicates that there is a one-way causal relationship between FDI and tourism. Guo [13]et al. studied the influence of FDI on tourism, and proposed countermeasures for the utilization of foreign capital in tourism industry. Tisdell et al.[14] showed that the rapid growth of China's tourism industry promoted foreign investment in China. Bao [15]-[19] worked out a series of researches on the correlation between China's inbound tourism and OFDI, for instance, the relationship between the inbound business travel and OFDI, spatial gather and pervasion mechanism of inbound business tourism and OFDI, the time and space coupling of inbound business tourism and FDI, the dislocation of inbound business travel and FDI.

In general, no matter from the perspective of domestic or international studies, the research on the correlation between outbound tourism and OFDI in tourism industry from China has not yet been found. In order to enrich the research work of OFDI of China, this paper uses the lagging regression model from econometrics to investigate the correlation between tourism industry OFDI and outbound tourism.

\section{Methodology}

\section{Theoretical Framework}

Time lag effect widespread exists in the process of economic operation. Some economic variables are not only influenced by various factors of the same period, but also by the past times, sometimes even by themselves in the past. Therefore, the lagged variable model is needed to explain economic phenomenon[20]. For tourism investors, besides the scale of outbound tourists from home country, the information about previous investment is also extremely important. To estimate the quantitative correlation, the lagging regression model in econometrics is employed. The infinite distribution lagging model is shown below:

$$
\mathrm{Y}_{\mathrm{t}}=\alpha+\beta_{0} \mathrm{X}_{\mathrm{t}}+\beta_{1} \mathrm{X}_{\mathrm{t}-1}+\beta_{2} \mathrm{X}_{\mathrm{t}-2}+\ldots+\mathrm{u}_{\mathrm{t}} \text {. }
$$

It can be found from(1) that there is an infinite lagging variable in the infinite distribution lagging model. The number of sample observation is limited, so it is impossible to estimate it directly. To make the model work, some constraints or assumptions must be applied to transform the structure of the model. The method of Koyck is used to overcome the difficulty of freedom loss, the multiple co-linear and the select of lag length. After Koyck method, an infinite distribution lagging model is converted into a self-regression model (2) which could estimate smoothly.

$$
\mathrm{Y}_{\mathrm{t}}=\alpha+\beta \mathrm{X}_{\mathrm{t}}+\beta_{1} \mathrm{Y}_{\mathrm{t}-1}+\mathrm{u}_{\mathrm{t}} \text {. }
$$

The equation greatly simplifies the model structure and maximizes the degree of freedom. It also solves the problem that the lag length is difficult to be determined and alleviates the multiple co-linearity.In this paper, considering the influence of the current and the lag period independent variable, the model can be expressed as(3):

$$
\text { OFDI }_{\mathrm{t}}=\alpha+\beta \text { COUT }+\beta_{1} \mathrm{OFDI}_{\mathrm{t}-1}+\mathrm{u}_{\mathrm{t}} \text {. }
$$

OFDI represents the outbound direct investment of tourism, and COUT represents the scale variation of outbound tourism, and $t$ is the current time.

\section{Data and Resource}

The object of this study is outbound tourism's annual change and China's OFDI flows on tourism industry. From the China FDI bulletin which is published by the Ministry of Commerce of the People's Republic of China and National Bureau of Statistics of the People's Republic of China, 
there is no definite item about the OFDI volume on tourism because of the tourism industry's statistics complexity. Since the lodging and catering services is the main part of tourism industry, the data of this item is employed to represent the OFDI from China on tourism. The change rate of outbound tourism(COUT) need to be calculated. The original data comes from the official website of China National Tourism Administration. All the data is based on the period of 2004-2016.

Table 1 Annual Change Rate of China Outbound Tourism and FDI in Accommodation and Catering Industry

\begin{tabular}{|c|c|c|c|c|c|}
\hline Year & $\begin{array}{c}\text { Annual change } \\
\text { rate[\%] }\end{array}$ & $\begin{array}{c}\text { FDI Flows } \\
\text { [Millions of USD] }\end{array}$ & Year & $\begin{array}{c}\text { Annual change } \\
\text { rate[\%] }\end{array}$ & $\begin{array}{c}\text { FDI Flows } \\
\text { [Millions of USD] }\end{array}$ \\
\hline 2004 & 42.7 & 2.03 & 2011 & 22.4 & 116.93 \\
\hline 2005 & 7.5 & 7.58 & 2012 & 18.4 & 136.63 \\
\hline 2006 & 11.3 & 2.51 & 2013 & 18.0 & 82.16 \\
\hline 2007 & 17.6 & 9.55 & 2014 & 9.0 & 244.74 \\
\hline 2008 & 11.9 & 29.50 & 2015 & 9.0 & 723.19 \\
\hline 2009 & 4.0 & 74.87 & 2016 & 4.3 & 1625.49 \\
\hline 2010 & 20.4 & 218.20 & & & \\
\hline
\end{tabular}

\section{Empirical Analysis}

Eviews6.0 is employed for model analysis. The results are shown in table 2.

Table 2 Lagging Regression Model Test Results

\begin{tabular}{|c|c|c|c|c|}
\hline Variable & Coefficient & Standard Error & T-test & Prob. \\
\hline C & 177.438 & 94.401 & 1.880 & 0.093 \\
\hline COUT & -14.962 & 6.023 & -2.484 & 0.035 \\
\hline OFDI(-1) & 2.089 & 0.189 & 11.081 & 0.000 \\
\hline
\end{tabular}

$$
\mathrm{R}_{2}=0.945 \text { Adjusted } \mathrm{R}_{2}=0.932 \quad \mathrm{~F}=76.852 \quad \mathrm{DW}=2.717
$$

According to the table 2,regression model is shown as (4):

$\mathrm{OFDI}_{\mathrm{t}}=177.438-14.962 \mathrm{COUT}+2.0890 F D I_{\mathrm{t}-1}$.

$$
(1.880) \quad(-2.484) \quad(11.081)
$$

\section{Dubin-H Test}

For the model which includes lag explanatory variable, Durbin-h statistic test is adopted to examine whether the random disturbance item is self-related or not. The test equation is shown as below:

$$
h=\left(1-\frac{d}{2}\right) \sqrt{\frac{n}{1-n \operatorname{Var}\left(\beta_{1}\right)}} \text {. }
$$

$\mathrm{d}$ is DW value statistic, $\mathrm{n}$ is the number of valid samples, and $\operatorname{Var}\left(\beta_{1}\right)$ is the estimation variance of the regression coefficient of $Y_{t-1}$. The durbin-h test of equation (3) equals -1.526.

Durbin-h proved that the limit distribution of $\mathrm{h}$ statistic is the standard normal distribution under the assumption of $\rho=0$. While the significance level $\alpha=0.05$, the critical value was 1.96 . Since $|\mathrm{h}|<\mathrm{h}_{\alpha / 2}$, we accept the null hypothesis, indicating that there is no first-order auto-correlation in the auto-regressive model. 


\section{Result and Discussion}

\section{Result}

According to the empirical analysis of China outbound tourism and China's OFDI on lodging and catering industry from 2004 to 2016, the following conclusions are drawn:

1)the accommodation and catering industry OFDI will be affected by its past. Investment in the first phase of accommodation and catering could pull the latter phase. The previous stage of OFDI increased by 1 unit, resulting in latter OFDI that increase 2.089 units.

2)the China's OFDI on accommodation and catering industry will be negatively affected by the changes of the outbound tourism scale. Outbound tourism volume increased by 1 percent compared with last year, while the foreign direct investment in accommodation and catering industry declined by $\$ 149$ million in the same year. Given the topic and length of the article, the negative correlation between them doesn't be discussed.

\section{Discussion}

For the above results, the following suggestions are proposed:

1)The relevant government departments should strengthen information services. In view of the impact of previous information on tourism investment, government departments should strengthen communication with international tourism, business and trade organizations. To provide domestic tourism enterprises with information about the political, economic, market and overseas enterprises of various countries or regions, the government should build a convenient, timely and accurate information platform for outbound investment. The government need to accelerate the pace of outbound investment by domestic tourism enterprises and expand the scale of outbound investment.

2)Under the macro background of the rapid development of China's outbound tourism, tourism industry OFDI faces opportunities. It is critical to grasp the relationship between the two aspects. At present, the tourism industry OFDI from China has dislocation with the development of Chinese outbound tourism. China's service industry still faces the situation of foreign exchange leakage. Therefore, in the process of foreign direct investment in tourism planning, the enterprises should consider the status quo of China's outbound tourism in time and make a contribution to earn back the foreign exchange and service Chinese tourists.

\section{Acknowledgement}

The study is funded by National Natural Science Foundation of China "The Spatial Evolution Mechanism and Location Selection of China's Direct Investment in the United States”(No.41671118).

\section{Reference}

[1] Jun Yang. An Analysis of “Overgrowth and Over-Consumption” in China' s Outbound Travel and Policy Orientation[J]. Tourism Tribune,2006,21(6):65-68.

[2] Bo Ma, Min Kou. An Initial Study on the Development of China' s Outbound Travel and Its Impact[J]. Tourism Tribune, 2006,21(7):24-28.

[3] Han Shen. Advantages of Industrial Development in China 's Outbound Tourism[J]. Tourism Tribune, 2011,26(7):6-7.

[4] Xiangnong Li,Junping Yan,Ying Chen. Characteristics and Countermeasures of Foreign Investment of Chinese Tourism Industry[J]. Resource Development\&Market,2014,30(2):225-228.

[5] Fuhua Bao,Mei-ning Zhu. An Analysis of Characteristics and Related Factors of China' s Foreign Direct Investment in Tourism Industry[J]. Commercial Research,2017(7):173-177. 
[6] Adrian Bull. Australia Tourism: Effects of Foreign Investment[J]. Tourism Management, 1990, 11(4).

[7] William Purcell, Stephen Nicholas. Japanese Tourism Investment in Australia: Entry Choice, Parent Control and Management Practice[J]. Tourism Management,2001,22(3):245-257.

[8] Kumi Endo. Foreign Direct Investment in Tourism----Flows and volumes[J]. Tourism Management, 2006,27(4):600-614.

[9] Hanqin Qiu Zhang, Basak Denizci Guillet, Wendy Gao. What Determines Multinational Hotel Groups' Locational Investment Choice in China?[J]. International Journal of Hospitality Management,2012,31(2):350-359.

[10]Ming Gao. Scale of Inbound Tourism and FDI Dependence[J]. Tourism Forum,2011,4(1):44-50.

[11] Guanghua Wan, Shumei Tang. Foreign Direct Investment and Tourism Industry: Evidence from China[J]. World Economic Papers,2006(5):49-59.

[12] Tang S, Selvanathan E A, Selvanathan S. The Relationship between Foreign Direct Investment and Tourism: Empirical Evidence from China[J]. Tourism Economics,2007,13(1).

[13] Xudong Guo. Empirical Analysis of Foreign Direct Investment and Tourism Competitiveness[J]. Inquiry into Economic Issues,2001(7):73-77.

[14] Tisdell C, Wen J. Investment in China's Tourism Industry: Its Scale, Nature, and Policy Issues[J]. China Economic Review,1991,2(2).

[15] Fuhua Bao, Ying Chen. Study on the Spatial Mismatch between Foreign Direct Investment and Inbound Business Tourism in Chinese Mainland[J]. Journal of Zhejiang University(Science Edition), 2016,43(4):465-475.

[16] Fuhua Bao, Ying Chen. Gravity Evolution Comparative Research of Inbound Business Tourism and Foreign Direct Investment on Chinese East[J]. Commercial Research,2015(11):186-192.

[17] Fuhua Bao, Ying Chen. Study on the Relationship between FDI and Inbound Business Tourism: Take Beijing, Shanghai and Guangzhou as Examples[J]. Statistics\& Information Forum, 2016, 31(4): 80-86.

[18] Fuhua Bao,Ying Chen,Gennian Sun. The Study on the Spatial Gather-Pervasion and the Formation Mechanism and Inbound Business Tourism and FDI[J]. Economic Management, 2015(12):124-134.

[19] Fuhua Bao, Ying Chen. A Study on the Interactive Relationship between Inbound Business Tourism and FDI: Based on the Samples of Beijing, Shanghai and Guangzhou[J]. Shanghai Journal of Economics,2016(6):53-61.

[20] Hao Pang. Econometrics. Beijing: Science Press(Second Edition): 177-194. 